\title{
Influences of Agricultural Practices in the Canton Erdé-Pala Chad Vegetation
}

\author{
Daniel Tchobsala ${ }^{1}$, Vroumsia $\mathrm{Toua}^{2}$, Fonone $\mathrm{Nafou}^{2}$ and Kaira Denis ${ }^{2}$ \\ 1. Department of Biological Sciences, University of Ngaoundere, PO Box 454, Cameroun \\ 2. Department of Life Sciences and Earth, University of Maroua, PO Box 55, Cameroun
}

\begin{abstract}
The study, conducted in the Canton Erdé-Pala Chad, aims to i) list the different cultural practices, ii) study their impact on the vegetation and iii) determine the methods of co-management of these cultural practices. The surveys were realized on 50 households in the village and phytosociological plants in corn, millet, cotton and peanuts cultures. The data analysis by statgraphic and Excel and Principal Component Analysis (PCA) showed that maize production (1,200 kg/ha) ranked first at the expense of cotton $(640 \mathrm{~kg} / \mathrm{ha})$. They negatively affect climate change (temperature increase (26\%), rain drop (20\%), land reclamation (18\%) and flooding $(12 \%))$. Surveys of vegetation on three acres cotton fields $(76.17 \%)$, millet $(81.06 \%)$, corn $(80.32 \%)$ and groundnut $(83.56 \%)$ showed that there is no significant difference $(P=0.05)$ on the specific contribution of wood of different types of farming practices. Adventists species herbacious like Thelepogon elegans (27.84\%), Hyptis spicigera (19.31\%), Teramnus labialis (15.86\%) have most important contributions in specific cultures. Methods of crop treatments have a destructive impact on the environment and the loss of biodiversity and the invasion of crops by adventists. Co-management, crop rotation, association of cultures, community forest management, agroforestry and training farmers in the use of inputs will reduce the potential risks of farming practices.
\end{abstract}

Key words: Influence, cultural practices, floristic composition, soil restoration, Chad.

\section{Introduction}

Agriculture in Chad, in general, and especially in the canton Erdé-Pala is an essential for the survival of peasant activities. To meet their needs, farmers make maximum use of the land and arable land is increasing [1]. Plowing with a hoe, hoe and plow by farmers influence on soils and vegetation. Intensive practice culture, without rotation destroys the soil [2]. Nowadays, new technics cultural and methods are introduced and taken place of traditional technic. The introduction of cash crop farmers rocked a situation of self-sufficiency in a situation of dependence [3], worked on the dynamics of agriculture and its impact on natural resources, without putting the action on the vegetation becomes increasingly zero [4], discusses in rural Moundang country, but has focused on how land management in Moundang. It is the massive and rapid

Corresponding author: Daniel Tchobsala, Ph.D., research fields: botanic and ecology. E-mail: tchobsala2002@yahoo.fr. destruction of the surrounding cultures for implementation. Strategies for biodiversity protection and sustainable development are scarcely integrated by the people of this area. It is fashionable to study the management of arable land and the protection of the environment for better living conditions of the Chadian population. Specifically, there is an inventory of different cultural practices developed in this area, to study the influence of these cultural practices on vegetation (influence of cultural practices on the floristic composition, inventory of endangered species disappearance) and assess management methods envisaged by the local population and the government.

\section{Materials and Methods}

\subsection{Presentation of the Study Area}

The study was conducted in the township Erdé-Pala in Chad Vridjibao village north latitude: $9^{\circ} 32^{\prime} 6^{\prime \prime}$ and longitude $15^{\circ} 9^{\prime} 52^{\prime \prime}$ with an area of $1,410 \mathrm{~km}^{2}$ (Fig. 1). It is bordered to the north by the cantons and Gouing 
Goï-Gouduom, to the east by the township Tagalog, to the south by the township Gouadji and west by the township Gifted. This localization excludes the town of Pala who is not part of the cantonal territory within a radius of $7 \mathrm{~km}$. The Canton-Erdé Pala has several soil types (sandy and sandy loam) suitable for growing sorghum, millet, sesame, peanuts, corn and cotton [5]. Climate Township Erdé-Pala is a sudanian climate. The vegetation consists of the Sudanese domain with precipitation ranging from 700 to 1,000 $\mathrm{mm}$, the Sahel region between 300 and $600 \mathrm{~mm}$ of rain, savannas to forest or woodland affinity Chad, the savanna woodlands composed overwhelmingly of Combretaceae. The main activities of the population are: agriculture, farming and logging.

\subsection{Methods}

\subsubsection{Interviews}

The interviews were conducted on a sample of 50 farmers. Open or semi-open questions were asked. The interview was either group before the court of the village chief, or in groups of 5 or even individually. Sheets field surveys were established to record species found in home gardens.

\subsubsection{Experimental and Vegetation Surveys}

The experimental device is a further randomized block with four treatments (millet, maize, groundnuts and cotton) and three repetitions. In total 12 plots of

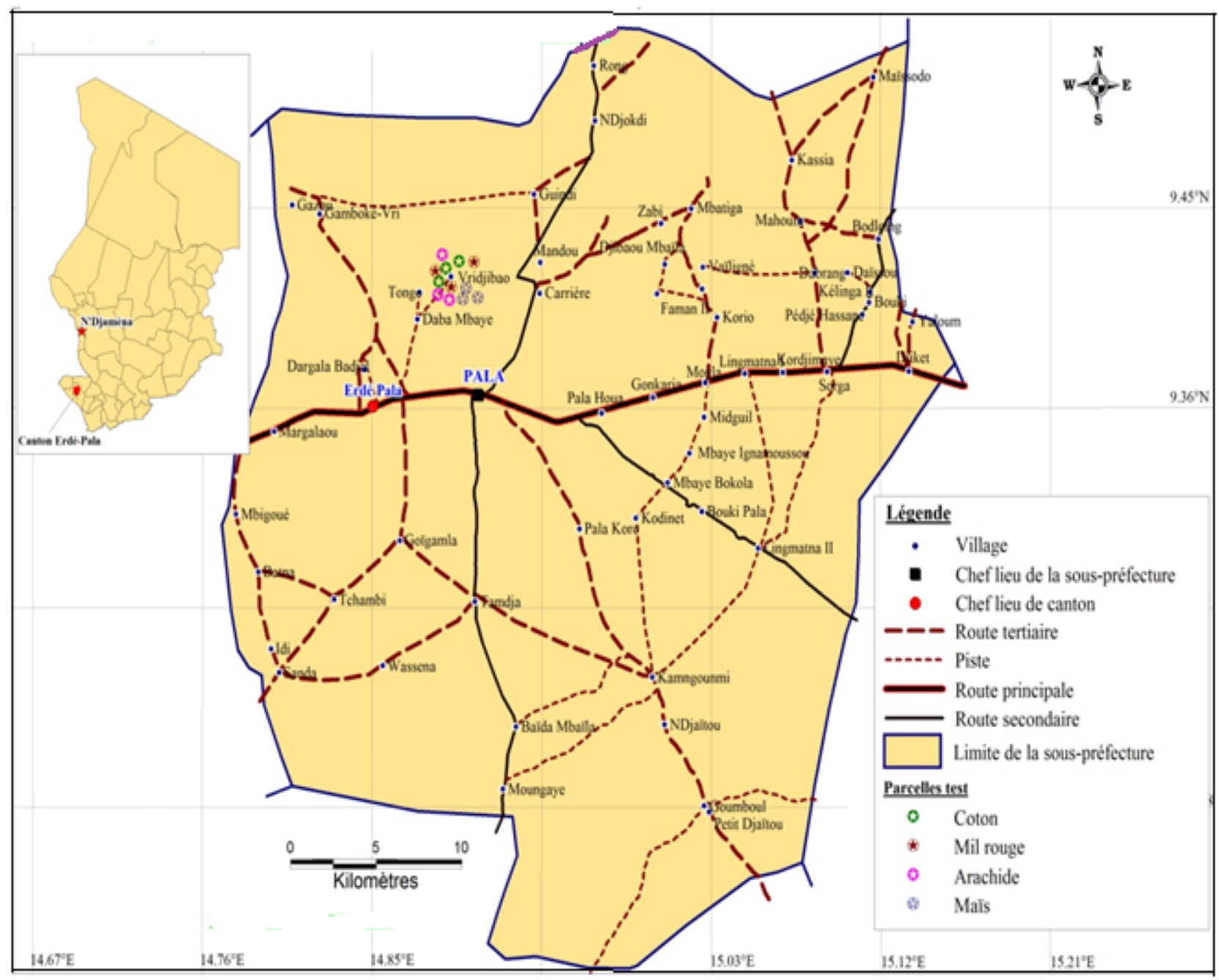

Legend: mais: maize, mil rouge: red millet, coton: cotton and arachide: peanuts.

Fig. 1 Map of geographical location of the study sites. 
$50 \times 50 \mathrm{~m}$ were used for surveys of woody vegetation in agricultural practices. The transects of $10 \times 50 \mathrm{~m}$ were defined by three people with a measuring tape. The fourth person was in charge of the survey of timber. The surveys focused on density, height, diameter and crown diameter (Fig. 2). Within each of the 12 plots used for recording woody species, five circles of $1 \mathrm{~m}$ radius are delimited with a measuring tape for surveys of invasive herbaceous crops. 5 circles are arranged in the following manner, in the center of a square of $50 \times$ $50 \mathrm{~m}$ and to each of four corners of the square. The statement of the herbaceous layer was involved 4 people, 3 people to limit the 5 circles and someone to take notes. Only the presence of the herbaceous layer was noted. The species were identified on site scientific names or common names (Fig. 3). Those which have not been identified on the site were made in a herbarium and identified in Herbarium of Wakwa Ngaoundere.

\subsection{Data Analysis Methods}

The data was analyzed taking into account the following parameters:

Centesimal rate (FCi) of a given species which is the ratio of the number of occurrences of the species (NPi) the total number of points sampled (PE) as a percentage.
It is calculated using the formula:

$$
F C_{i}=N P_{i} / P E \times 100 ;
$$

The specific contribution (CSi) is defined as the ratio of the frequency elemental (FCi) the sum of the frequencies centesimal ( $\mathrm{FCn}$ ) of all species sampled. It is calculated using the formula:

$$
C S i=\Sigma F C i / F C n \times 100
$$

The overall recovery $(\mathrm{R})$ is the ratio, expressed as a percentage of the number of points where there is the presence of at least one species and the number of sample points.

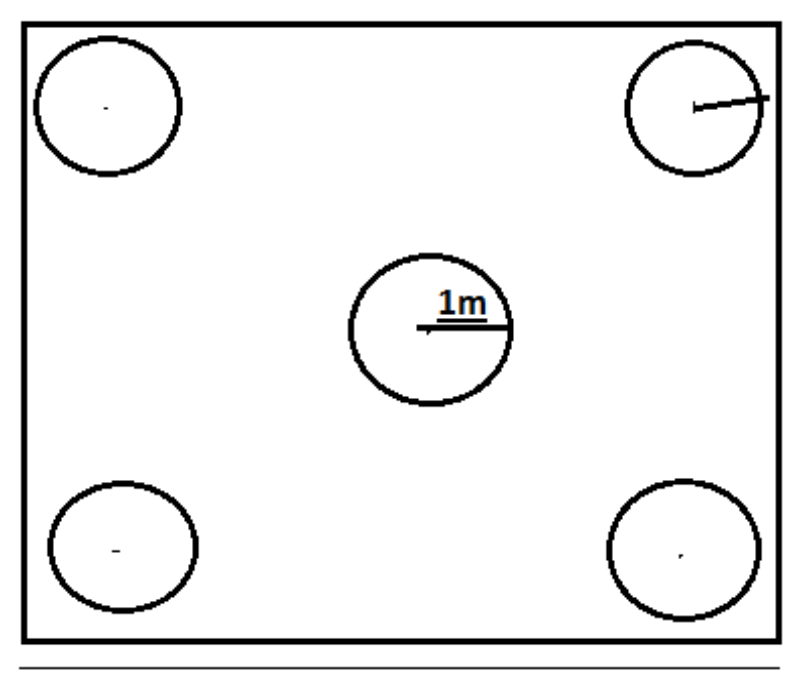

$\underline{50 \mathrm{~m}}$

Fig. 2 Experimental setup.

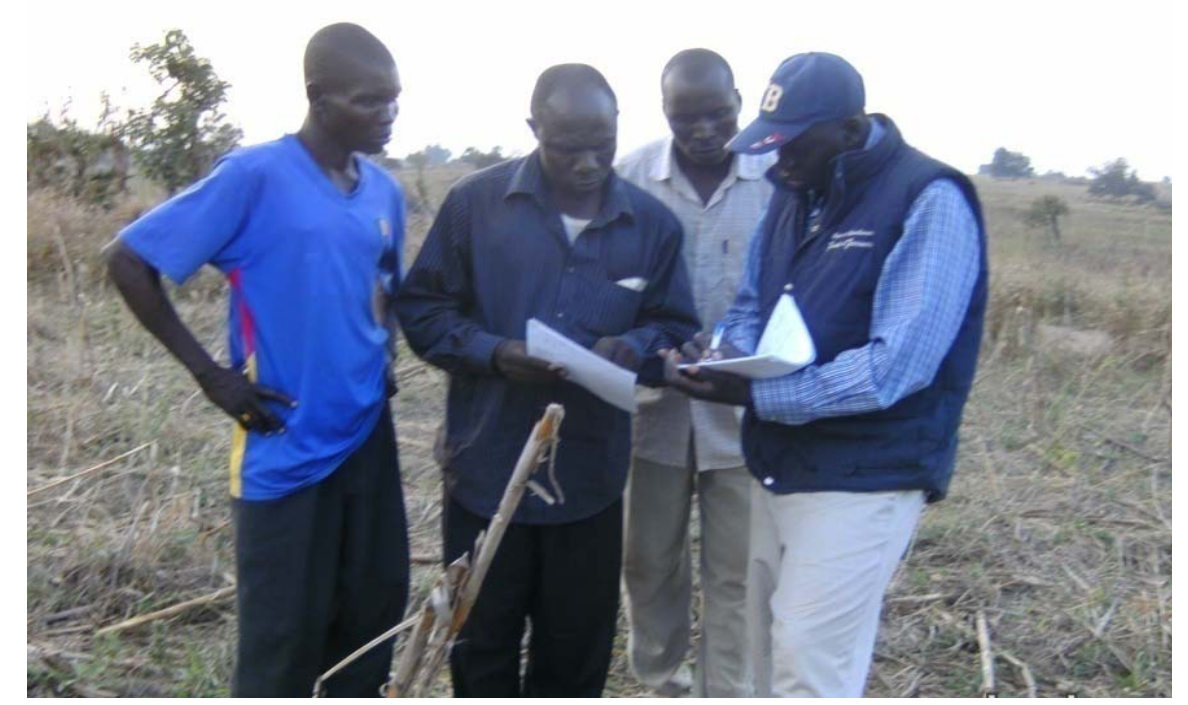

Fig. 3 Statement of the vegetation in the village of Vridjibao Erdé-Pala in Chad. 
$\mathrm{R}=\mathrm{B} / \mathrm{A} 100$ where, $\mathrm{A}$ is the point number of drive and $\mathrm{B}$, the number of points where the vegetation is present.

\subsection{Absolute and Relative Densities}

The absolute density (Ni) or absolute abundance of a taxon is the total number of stems of this taxon per unit area. The relative density $(\mathrm{dr})$ or relative abundance is the ratio between the number of individuals of a species and the total number of all individuals of all species encountered on a surface considered multiplied by 100 .

\subsection{Absolute and Relative Dominance}

Dominance expresses the influence of a species in a community. The relative dominance (Dr) is the ratio of the basal area ( $\mathrm{Sb}$ ) of a species on the total basal area of all individuals encountered; $\mathrm{Sb}=\pi \cdot \mathrm{D}^{2} / 4, \mathrm{D}$ is the diameter of the rod. The total basal area (SBT) is the total sum of all the basal areas of all stems per hectare treated. It is expressed in $\mathrm{m}^{2} / \mathrm{ha}$.

\subsection{Value Importance Curtis}

The three statistics (dominance, frequency and relative density) are commonly used together and their sum is equal to "Value importance Curtis". Its value ranges between 0 and 300 .

\subsection{Technical Data Processing}

The data collected in the field were collected and processed by Microsoft Word, Microsoft Excel and so the means of descriptive statistics and Principal Component Analysis (PCA) software was included.

\section{Results}

\subsection{Types of Crops Grown in Vridjibo Village}

Fig. 4 shows the principal types of crops system practiced in the village. Maize cultivation takes place in the home garden, benefiting from the household garbage.

\subsection{Tools and Methods used in Farming Practices}

Fig. 5 shows that the plow-hoe combination (44\%) is much practiced by farmers to clear and plow the fields, because this method keeps fields clean and eliminate any competition with the Adventists. Use of herbicide-hoe $(24 \%)$ is the second technique for clearing farmland. This method is to burn the herbs with the chemicals (Roundup) and plant and wait at times for up to 45 days before the first plowing. Few people practice tractor-hoe combination $(6 \%)$ because it is not well known in the village, leaving hollows in the field causing erosion. The statistical analysis shows that there are significant differences between the different farming techniques $(P=0.05)$.

The Fig. 6 shows four (4) different techniques of plowing in the fields. It is plowing with the tractor, ass plowing, horse and cattle plowing. Plowing horse and the donkey are increasing for the sole reason that farmers are unable to buy the horse hitch given the very high price.

\subsection{Area and Production of Different Types of Crops}

Fig. 7 shows the different farming system with their production according to the different areas.

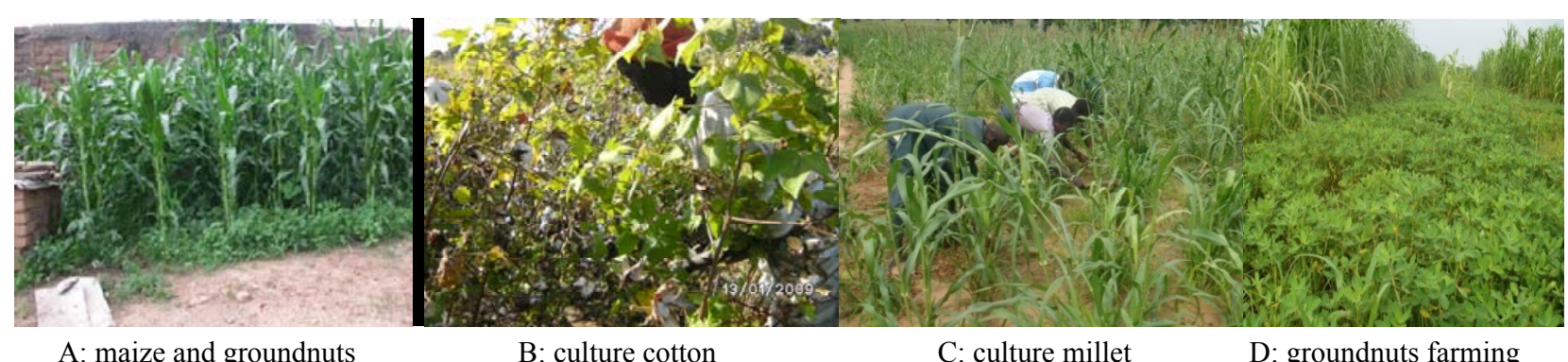

A: maize and groundnuts

B: culture cotton

C: culture millet

D: groundnuts farming

Fig. 4 Types of crops grown in Vridjibo village of Canton Erdé-Pala Chad. 


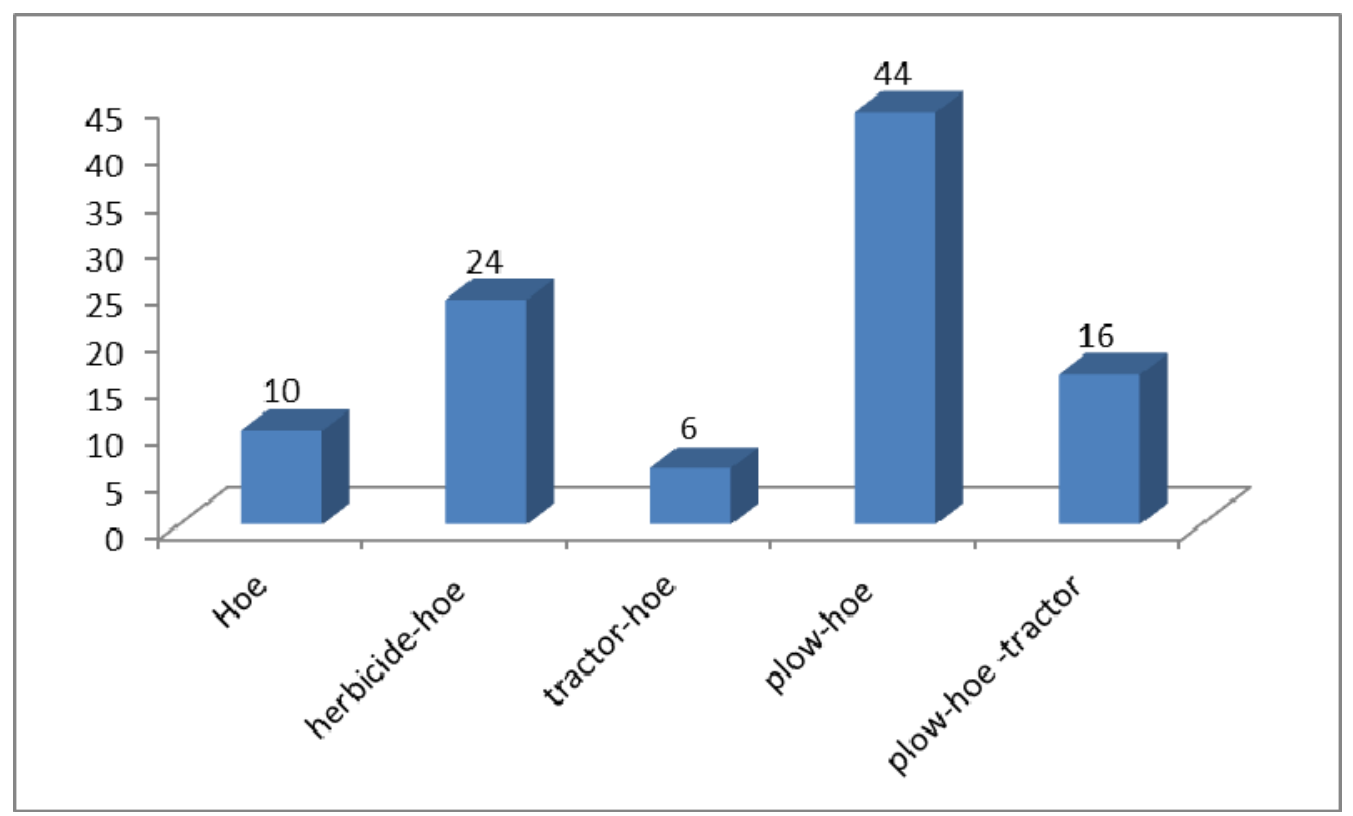

Fig. 5 Techniques of cultivation practices in Vridjibo village of Canton Erdé-Pala Chad.

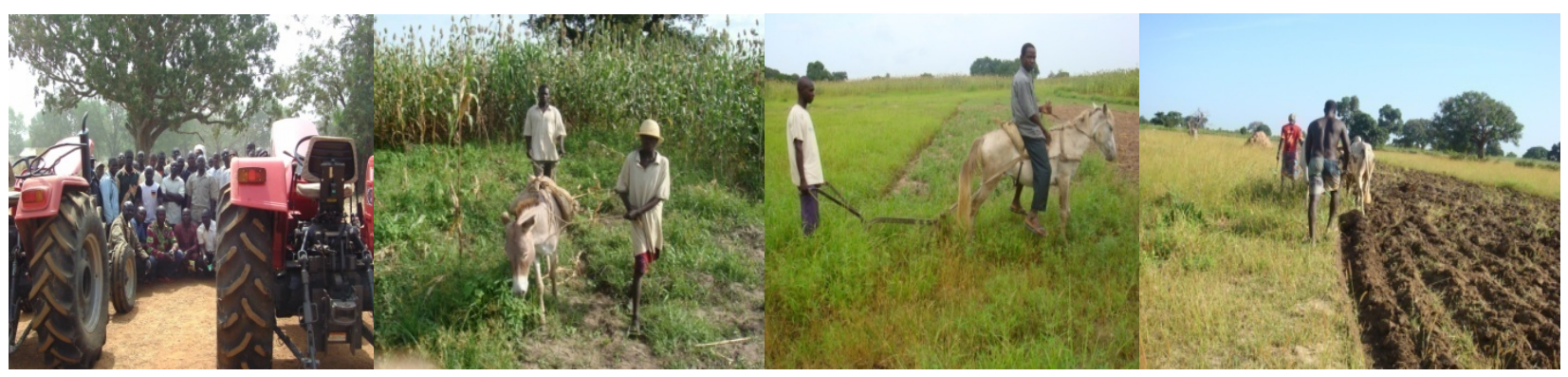

A: tractor ploughing

B: donkey ploughing

C: horse ploughing

D: cattle ploughing

Fig. 6 Different tillage practices in Vridjibo village of Canton Erdé-Pala Chad.

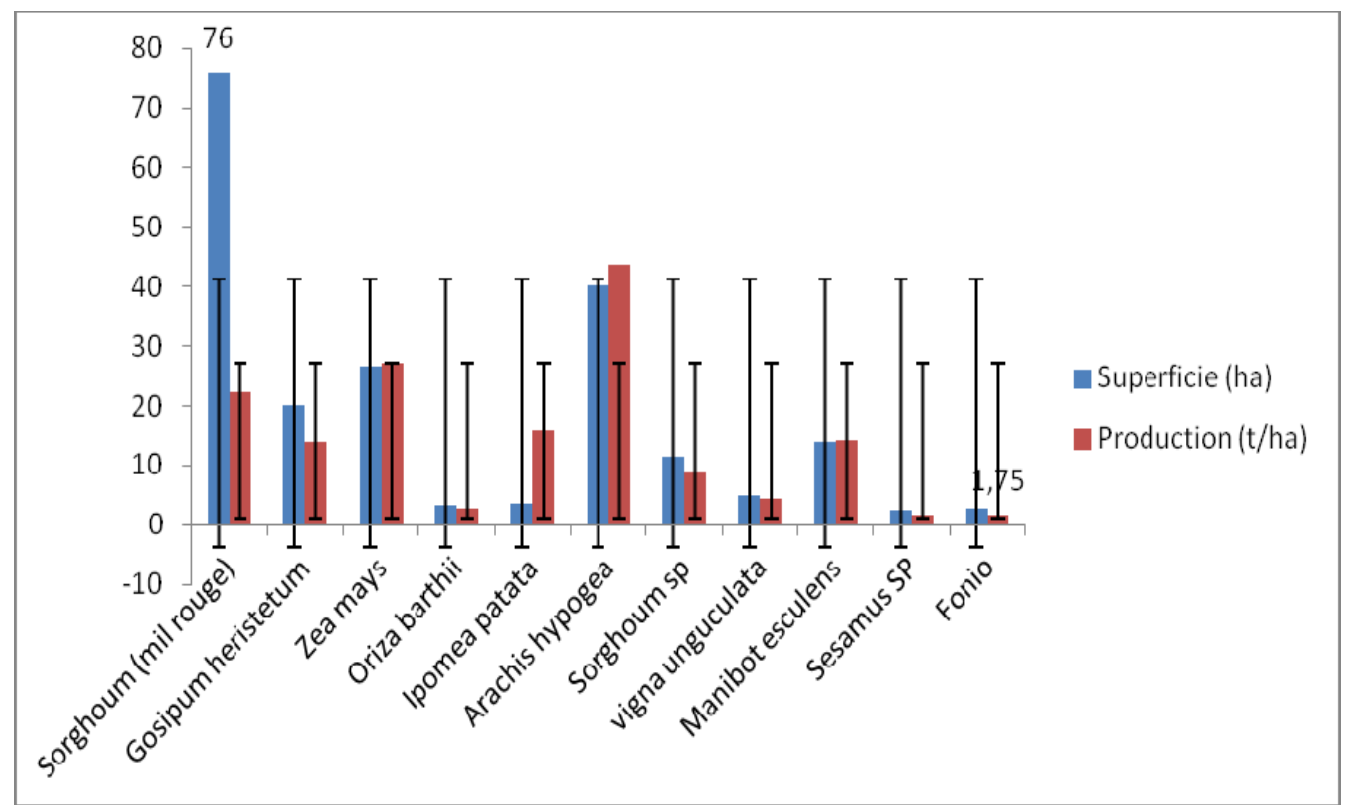

Legend: superficies: area.

Fig. 7 Estimated area and production of agricultural practices in Vridjibo village of Canton Erdé-Pala Chad. 
Millet area (76 t/ha) is large compared to other crops, yet its production is low $(22.24 \mathrm{t} / \mathrm{ha})$. It is the staple food, but its production is low due to Striga hermonthica in poor soil and flooding in the township.

\subsection{Production Estimation of Four Experimental farms Practices in Vridjibo Village}

Surveys of local populations on the four crops (millet, groundnut, cotton and maize) experiment has identified four processes (weeding, ridging, use of herbicides and chemical and organic fertilizers) used in farming. Fig. 8 shows that the maize fields $(1,200$ $\mathrm{kg} / \mathrm{ha})$, groundnut $(900 \mathrm{~kg} / \mathrm{ha})$ and cotton $(840 \mathrm{~kg} / \mathrm{ha})$ have good yields due to the use of chemical fertilizers and weeding. For cons, the yields of millet field (310 $\mathrm{kg} / \mathrm{ha}$ ) is very low due to the lack of chemical fertilizers, yet it has been weeded. The production of different crops is proportional to the different yields. The combination of chemical fertilizer and weeding provides good yields.

\subsection{Influence of Crops on Height, Diameter at Breast} Height (DBH), Basal Area and Density of Woody Species

Protected or regenerated trees in millet farms have heights $(37.86 \mathrm{~m} / \mathrm{ha})$, or $2.52 \mathrm{~m} / \mathrm{ha}$ on average higher, compared to maize farms $(3.33 \mathrm{~m} / \mathrm{ha})$ and groundnuts (3.52 m/ha) (Table 1). In general, farmers leave the large trees in the fields of millet, for shading and for animals resting during the dry season. These animals leave their droppings to fertilize the soil. These species are Daniellia oliveri (12.23 m/ha) and Ficus glumosa $(12.23 \mathrm{~m} / \mathrm{ha})$, which have the highest values. These species are, for the most part protected by the farmers in their different farms.

Moreover, the diameter at breast height (DBH) of the tree species shows that large trees are maintained in much the millet field with a DBH $(29.84 \mathrm{~m} / \mathrm{ha})$ for all 15 species. Larger trees Daniellia oliveri $(8.53 \mathrm{~m} / \mathrm{ha})$, Mangifera indica $(8.06 \mathrm{~m} / \mathrm{ha})$ and Azadirachta indica $(7.51 \mathrm{~m} / \mathrm{ha})$ were higher DBH in four types of farms. The basal area of woody species in the millet fields $\left(3,455.15 \mathrm{~m}^{2} / \mathrm{h}\right)$ and cotton $\left(171.15 \mathrm{~m}^{2} / \mathrm{ha}\right)$ have very high values of basal area. These species Daniella oleveri $\left(1,505.98 \mathrm{~m}^{2} / \mathrm{ha}\right)$, Ficus glumosa (1287.60 $\left.\mathrm{m}^{2} / \mathrm{ha}\right)$, Balanites aegyptiaca $\left(335.18 \mathrm{~m}^{2} / \mathrm{ha}\right)$ and Mangifera indica $\left(298.50 \mathrm{~m}^{2} / \mathrm{ha}\right)$ are occupied much more space in the farms because of their very large canopy. The areas occupied by these species will result in reduced crop yields because all feet crops under trees will fight to get the light to carry out photosynthesis.

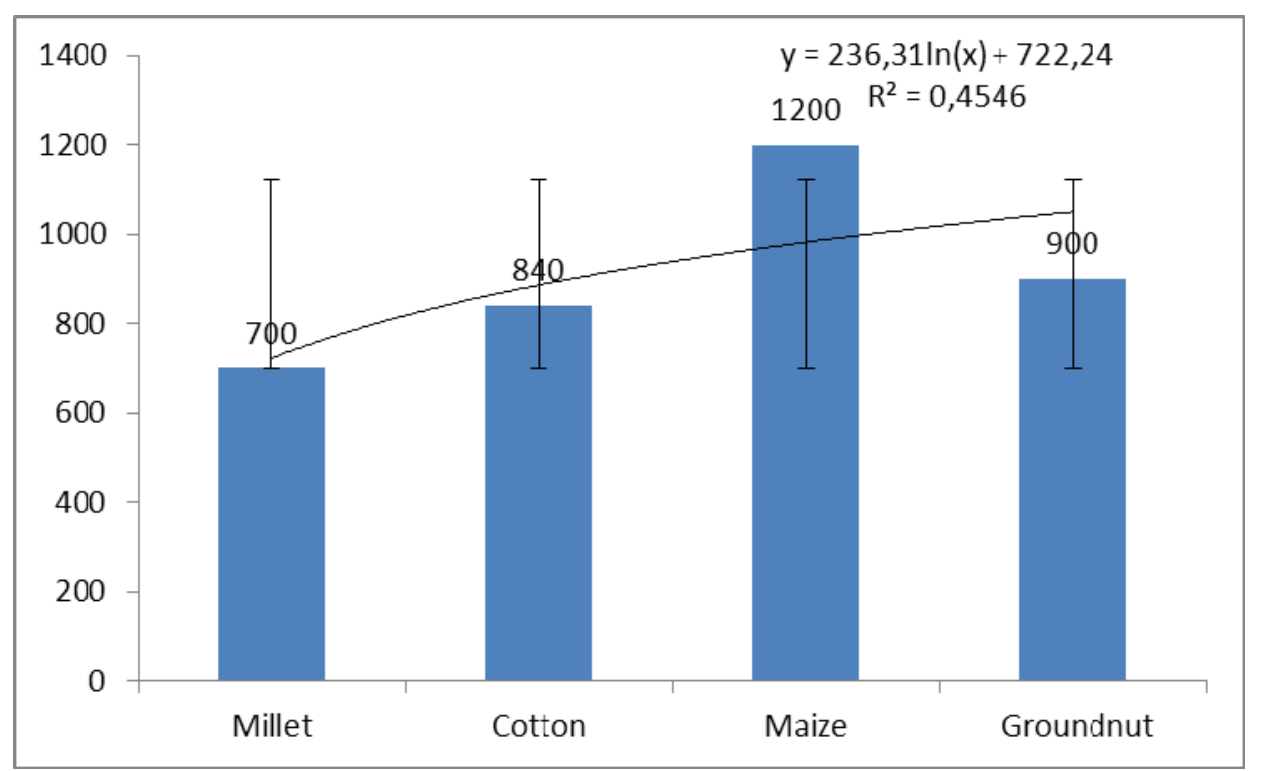

Fig. 8 Production of four experimental farms practices in Vridjibo village (kg/ha). 
Table 1 Influence of crops on the height, DBH, basal area and density of woody species.

\begin{tabular}{|c|c|c|c|c|c|c|c|c|c|c|c|c|c|c|c|c|}
\hline \multirow{2}{*}{ Especies } & \multicolumn{4}{|c|}{ Height $(\mathrm{m} / \mathrm{ha})$} & \multicolumn{4}{|c|}{ DBH $(\mathrm{m} / \mathrm{ha})$} & \multicolumn{4}{|c|}{ basal area $\left(\mathrm{m}^{2} / \mathrm{ha}\right)$} & \multicolumn{4}{|c|}{ density (stems/ha) } \\
\hline & Cotton & Millet & Maize & Grounnuts & Cotton & Millet & Maize & Grounnuts & Cotton & Millet & Maize & Grounnuts & Cotton & Millet & Maize & Grounnuts \\
\hline 1. Acacia radiana & 0.56 & 0.00 & 0.00 & 0.00 & 0.12 & 0.00 & 0.00 & 0.00 & 5.10 & 0.00 & 0.00 & 0.00 & 3.00 & 0.00 & 0.00 & 0.00 \\
\hline 2.Acacia sieberiana & 0.00 & 0.00 & 0.29 & 0.99 & 0.00 & 0.00 & 0.06 & 0.02 & 0.00 & 0.00 & 1.84 & 21.39 & 0.00 & 0.00 & 0.75 & 1.50 \\
\hline 3.Azadirachta indica & 0.00 & 3.62 & 0.00 & 0.00 & 0.00 & 7.51 & 0.00 & 0.00 & 0.00 & 11.94 & 0.00 & 0.00 & 0.00 & 3.00 & 0.00 & 0.00 \\
\hline $\begin{array}{l}\text { 4.Balanites } \\
\text { aegyptiaca }\end{array}$ & 0.38 & 5.06 & 0.00 & 0.75 & 0.11 & 0.90 & 0.00 & 0.07 & 3.97 & 326.69 & 0.00 & 4.52 & 1.50 & 0.75 & 0.00 & 0.75 \\
\hline $\begin{array}{l}\text { 5.Bauhinia } \\
\text { reticulatum }\end{array}$ & 0.75 & 0.00 & 0.00 & 0.00 & 0.11 & 0.00 & 0.00 & 0.00 & 0.00 & 0.00 & 0.00 & 0.00 & 59.30 & 0.00 & 0.00 & 0.00 \\
\hline 6.Daniellia oliveri & 0.00 & 12.23 & 0.00 & 0.00 & 0.00 & 8.73 & 0.00 & 0.00 & 0.00 & $1,506.00$ & 0.00 & 0.00 & 0.00 & 0.75 & 0.00 & 0.00 \\
\hline 7.Ficus glumosa & 0.00 & 9.49 & 0.00 & 0.00 & 0.00 & 3.49 & 0.00 & 0.00 & 0.00 & $1,287.60$ & 0.00 & 0.00 & 0.00 & 0.75 & 0.00 & 0.00 \\
\hline 8.Ficus sp. & 1.20 & 0.00 & 0.00 & 0.00 & 0.45 & 0.00 & 0.00 & 0.00 & 11.94 & 0.00 & 0.00 & 0.00 & 0.75 & 0.00 & 0.00 & 0.00 \\
\hline 9. Hyphaena thebaica & 0.00 & 0.77 & 0.00 & 0.00 & 0.00 & 0.03 & 0.00 & 0.00 & 0.00 & 2.98 & 0.00 & 0.00 & 0.00 & 1.50 & 0.00 & 0.00 \\
\hline 10.Mangifera indica & 0.00 & 2.70 & 0.00 & 0.00 & 0.00 & 8.06 & 0.00 & 0.00 & 0.00 & 298.50 & 0.00 & 0.00 & 0.00 & 0.75 & 0.00 & 0.00 \\
\hline 11.Moringa oleifera & 0.00 & 1.52 & 0.00 & 0.00 & 0.00 & 0.04 & 0.00 & 0.00 & 0.00 & 2.38 & 0.00 & 0.00 & 0.00 & 0.75 & 0.00 & 0.00 \\
\hline 12. Nauclea latifolia & 4.73 & 0.75 & 0.00 & 0.00 & 1.20 & 0.38 & 0.00 & 0.00 & 143.07 & 1.77 & 0.00 & 0.00 & 1.50 & 0.75 & 0.00 & 0.00 \\
\hline $\begin{array}{l}\text { 13.Piliostigma } \\
\text { thonningii }\end{array}$ & 0.00 & 1.43 & 1.50 & 0.84 & 0.00 & 0.26 & 0.11 & 0.06 & 0.00 & 1.43 & 3.08 & 9.34 & 0.00 & 3.00 & 0.75 & 9.00 \\
\hline 14.Psidium guajava & 0.00 & 0.00 & 1.54 & 0.00 & 0.00 & 0.00 & 0.45 & 0.00 & 0.00 & 0.00 & 3.97 & 0.00 & 0.00 & 0.00 & 0.75 & 0.00 \\
\hline $\begin{array}{l}\text { 15.Ziziphus } \\
\text { maurithiana }\end{array}$ & 0.98 & 0.30 & 0.00 & 0.94 & 0.30 & 0.45 & 0.00 & 0.05 & 7.07 & 15.90 & 0.00 & 7.07 & 5.25 & 0.75 & 0.00 & 1.50 \\
\hline
\end{tabular}


Concerning the density of wood species, cotton fields $(71.25 \mathrm{stems} / \mathrm{ha})$ was a best density than millet (12.75 stems/ha) and groundnut (12.75 stems/ha). These results show that farming practices promote the regeneration of trees even if they are cut each year. Species that have a strong power of regeneration are Bauhinia reticulatum (59.25 stems/ha), Piliostigma thonningii (12.75 stems/ha) and Ziziphus mauritiana (7.5 stems/ha).

The Principal Component Analysis shows that the variables, height, diameter at breast height, basal area and density were significantly correlated (Fig. 9). Along the axis F2 (19.93\%) Daniellia oliveri form a group with Piliostigma thonningii, Ficus glumosa Acacia sieberiana and Nauclea latifolia is negatively correlated with Hyphanea thebaica, Acacia radiana, Moringa oleifera groups. Species of the first group have a large overlap those of the second group. According to the F1 (34.90\%) axis, the group of Acacia radiana, Hyphanea thebaica Moringa oleifera form a less dense cloud. This group is opposed to the group Psidium guajava Acacia siberiana which has a low specific contribution from the four variables. According to the biplot axis (F1, F2: 54.83\%), there is a strong positive correlation $(\mathrm{R}=0.98, P \leq 0.01)$ between the group Daniellia olivera, Ficus glumosa and Piliostigma thonningii and Balanites aegyptiaca groups. Other species shaped cloud around the center and showing their small contribution to the four parameters, which are distinguished from others by their heights, their diameters at breast height (DBH), basal area and their densities. Negative values indicate that these variables are correlated in the opposite direction.

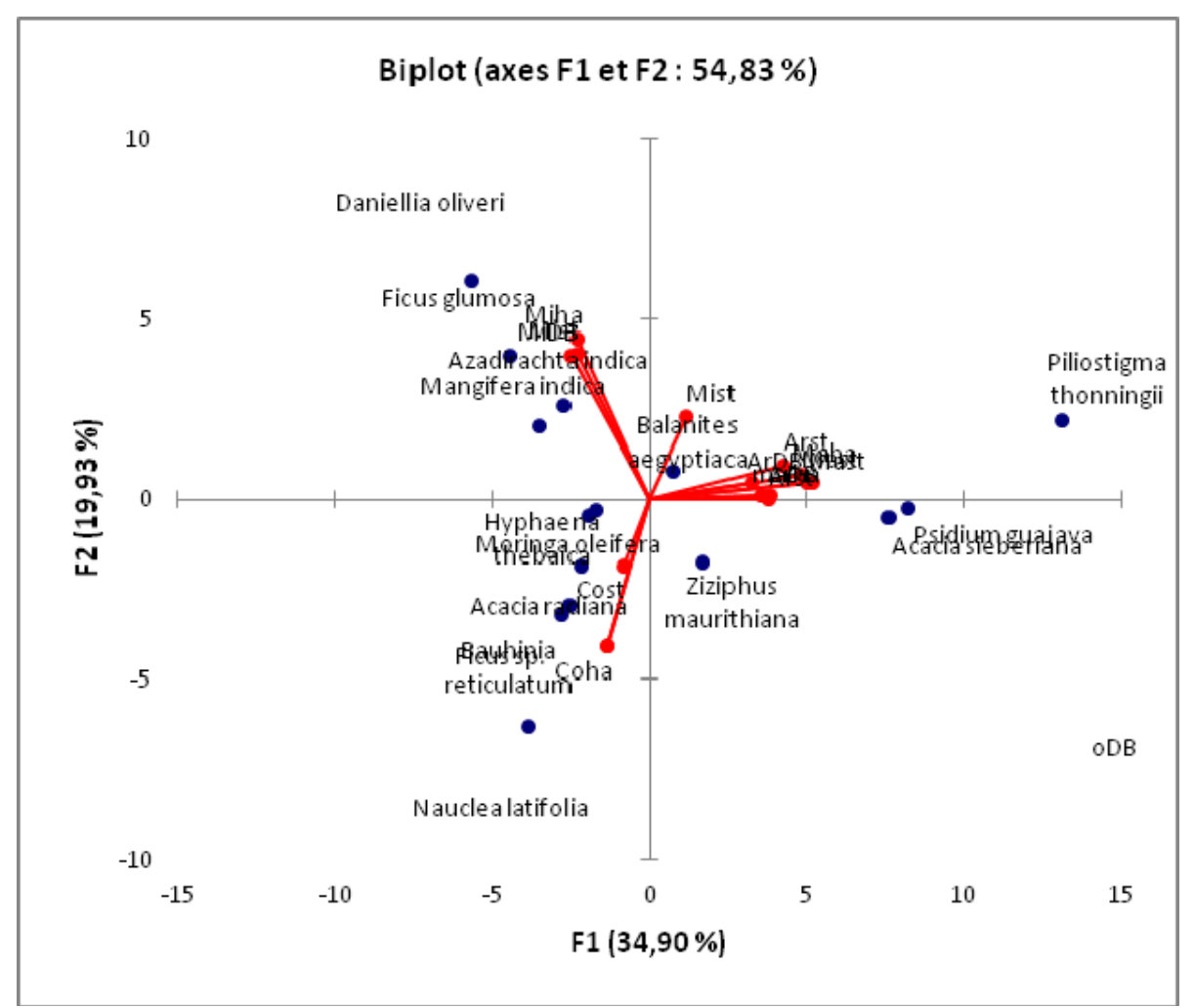

Legend: OMist: basal area of trees in the field of millet cost: basal area of trees in the cotton field, ARST: basal area in groundnuts field MAST tree basal area in the cornfield; codB : diameter at breast height (cotton) ARDB: diameter at breast height (groudnuts), MADB: diameter at breast height (corn) MidB: diameter at breast height (MIL), Miha: height of trees in the field millet Arha: tree height in peanut field, Maha: tree height in the cornfield, Coha: tree height in the cotton field.

Midr: Density of trees in the field of millet, Ardr: Density of trees in the cornfield, CODR: Density of trees in the cotton field. Madr: Density of trees in the cornfield.

Fig. 9 Principal component analysis of CSP woody species in crops of millet, peanuts, cotton and maize. 
3.6 Influence of Crops on Dominance, Frequency, Density and Importance Value for Woody Species

Table 2 shows the importance of species under the influence of farms practices in different farms. Despite threats of cuts of these species by the local population, the species Bauhina reticulatum present value on the importance of the order of $103.16 \%$ and $60 \%$ respectively for the cultivation of cotton and groundnuts farms. This shows that this species regenerates and adapts much more in the fields of cotton and groundnuts. Contrarily in the fields of millet and maize Daniellia oliveri and Piliostigma thonningii each have a value on the importance of the higher order of $58 \%$ and $118 \%$, respectively.

\subsection{Influence of Crops on the Specific Contribution of Invasive Species Cultures}

Of 126 invasive species of crops, 50 species have an important contribution in all four crops (Table 3). The species who have a high contribution in the four practices are Thelepogon elegans, Hyptis spicigera, Teramnus labialis, Commelina nigritana, Oldelandia corymbosa, Acanthospermum hispidum, Nensonia canescens etc. But the feeble contribution found in the Phyllanthus amarus, Triumfeta pentendra.

The Principal Component Analysis in the F2 axis (23.38\%) shows that the group Kyllinga squamutala, Commelina benghalensis, Penincetum pedicellatum are negatively correlated with the group Fimbristylis hispidum, Setaria Pumula. As groups Thelepogon elagans, Hyptis spicigera, Teramnus labialis, Acanthospermum hispidum, Oldelandia corymbosa are negatively correlated with the group Borrheria villosus, Gossipium hirstetum. This provision shows that groups Kyllinga squamutala and grouping Gossipium hirstetum have a very important contribution. Along the axis F1 (43.29\%) and the Fimbristylis hispidum Setaria pumila group are opposed to the group Borrheria villosus, Gossipium hirstetum forming around them very dense cloud. This difference shows that the species forming very dense cloud cover have average compared to group Kyllinga squamutala. According to the biplot (F1, F2: 66.67\%), there is a strong positive correlation between the group and the group Kyllinga squamutala, Acanthospermum hispidum in terms frequency and specific contribution and they are oriented in the same direction. Zea mays, Setaria pumila, has negative correlation and a significant difference (Fig. 10). They are frequent and contribute only their own culture. Acanthospermum hispidum and Setaria pumila are negative correlation. The clouds around the origin of the axes show a low specific contribution of these species. Zea mays and Arachys hypogea are negatively correlated against by Zea mays. Table 4 presented the high Matrice of correlation (Pearson (n)) betwen the fourth type of agricultural practice.

3.8 Influence of Crops on the Rate of Recovery of the Species

For woody species, millet field $(400 \%)$ has the largest collection in relation to other farms. The low recovery of wood in the cornfield (66.6\%) shows that it is due to start-ups, this is the case Piliostigma thonningii which has a high capacity for regeneration.

Chemical fertilizers used for cotton development positively influence the proliferation and growth of weeds of crops with a higher recovery $(1,220 \%)$ (Fig. 11). The species characterized this vegetation are Thelepogon elegans, Hyptis spicigera, Teramnus labialis, Nensonia canescens Oldelandia corymbosa, Sorghum bicolor, Penincetum pedicellatum, Acanthospermum hispidum, Commelina nigritana, Borrheria villosus, etc.

\section{Management Techniques of Cultural Practices}

\subsection{Restoration and Soil Fertilization}

Fig. 14 shows several restoration techniques and soil fertility used in the village. It is the use of organic 
Table 2 Relative dominance, relative density, relative frequency and relative importance value of woody species.

\begin{tabular}{|c|c|c|c|c|c|c|c|c|c|c|c|c|c|c|c|c|}
\hline \multirow[t]{2}{*}{ Scientifics names } & \multicolumn{4}{|c|}{ Cotton } & \multicolumn{4}{|c|}{ Millet } & \multicolumn{4}{|c|}{ Maize } & \multicolumn{4}{|c|}{ Grounnuts } \\
\hline & Dr & $\mathrm{dr}$ & $\mathrm{Fr}$ & IVR & $\mathrm{Dr}$ & $\mathrm{dr}$ & $\mathrm{Fr}$ & IVR & $\mathrm{Dr}$ & $\mathrm{dr}$ & $\mathrm{Fr}$ & IVR & $\mathrm{Dr}$ & $\mathrm{dr}$ & $\mathrm{Fr}$ & IVR \\
\hline 1. Nauclea latifolia & 83.59 & 2.11 & 0.00 & 85.7 & 0.05 & 5.88 & 8.00 & 14.00 & 0.00 & 0.00 & 0.00 & 0.00 & 0.00 & 2.27 & 0.00 & 2.30 \\
\hline 2. Bauhinia reticulatum & 0.00 & 83.16 & 20.00 & 103.16 & 0.00 & 0.00 & 0.00 & 0.00 & 0.00 & 0.00 & 0.00 & 0.00 & 0.00 & 59.85 & 0.00 & 60.00 \\
\hline 3.Ziziphus mauritiana & 4.13 & 7.37 & 20.00 & 31.50 & 0.46 & 5.88 & 8.00 & 15.00 & 0.00 & 0.00 & 0.00 & 0.00 & 16.71 & 7.58 & 20.00 & 44.00 \\
\hline 4.Ficus sp. & 6.98 & 1.05 & 20.00 & 28.03 & 0.00 & 0.00 & 0.00 & 0.00 & 0.00 & 0.00 & 0.00 & 0.00 & 0.00 & 0.76 & 0.00 & 0.80 \\
\hline 5.Balanites aegyptiaca & 2.32 & 2.11 & 20.00 & 24.43 & 9.46 & 5.88 & 8.00 & 24.00 & 0.00 & 0.00 & 0.00 & 0.00 & 10.68 & 3.03 & 20.00 & 34.00 \\
\hline 6. Acacia radiana & 2.98 & 4.21 & 20.00 & 27.19 & 0.00 & 0.00 & 0.00 & 0.00 & 0.00 & 0.00 & 0.00 & 0.00 & 0.00 & 3.03 & 0.00 & 3.00 \\
\hline 7.Ficus glumosa & 0.00 & 0.00 & 0.00 & 0.00 & 37.3 & 5.88 & 8.00 & 51.00 & 0.00 & 0.00 & 0.00 & 0.00 & 0.00 & 0.76 & 0.00 & 0.80 \\
\hline 8.Azadirachta indica & 0.00 & 0.00 & 0.00 & 0.00 & 0.35 & 23.50 & 17.00 & 41.00 & 0.00 & 0.00 & 0.00 & 0.00 & 0.00 & 3.03 & 0.00 & 3.00 \\
\hline 9.Piliostigma thonningii & 0.00 & 0.00 & 0.00 & 0.00 & 0.04 & 23.50 & 8.00 & 32.00 & 0.00 & 33.00 & 50.01 & 118.00 & 22.07 & 12.88 & 20.00 & 55.00 \\
\hline 10.Daniellia oliveri & 0.00 & 0.00 & 0.00 & 0.00 & 43.6 & 5.88 & 8.00 & 58.00 & 0.00 & 0.00 & 0.00 & 0.00 & 0.00 & 0.76 & 0.00 & 0.80 \\
\hline 11. Hyphaena thebaica & 0.00 & 0.00 & 0.00 & 0.00 & 0.09 & 11.8 & 8.00 & 20.00 & 0.00 & 0.00 & 0.00 & 0.00 & 0.00 & 1.52 & 0.00 & 1.50 \\
\hline 12.Moringa oleifera & 0.00 & 0.00 & 0.00 & 0.00 & 0.07 & 5.88 & 8.00 & 14.00 & 0.00 & 0.00 & 0.00 & 0.00 & 0.00 & 0.76 & 0.00 & 0.80 \\
\hline 13.Mangifera ndica & 0.00 & 0.00 & 0.00 & 0.00 & 8.64 & 5.88 & 8.00 & 23.00 & 0.00 & 0.00 & 0.00 & 0.00 & 0.00 & 0.76 & 0.00 & 0.80 \\
\hline 14.Psidium guajava & 0.00 & 0.00 & 0.00 & 0.00 & 0.00 & 0.00 & 8.00 & 8.30 & 0.00 & 33.00 & 0.00 & 77.99 & 0.00 & 0.76 & 0.00 & 0.80 \\
\hline \multirow{2}{*}{ 15.Acacia sieberiana } & 0.00 & 0.00 & 0.00 & 0.00 & 0.00 & 0.00 & 0.00 & 0.00 & 0.00 & 33.00 & 50.01 & 104.00 & 50.54 & 2.27 & 40.00 & 93.00 \\
\hline & 100.00 & 100.00 & 100.00 & 300.00 & 100.00 & 100.00 & 100.00 & 300.00 & 100.00 & 100.00 & 100.00 & 300.00 & 100.00 & 100.00 & 100.00 & 300.00 \\
\hline
\end{tabular}

Dr: relative diameter, dr: relative density, Fr: relative frequency, IVR: value relative importance. 
Table 3 Centesimal frequencies (Fc) and specific contribution (CSP) of some species based on the types of crops.

\begin{tabular}{|c|c|c|c|c|c|c|c|c|}
\hline & \multicolumn{2}{|c|}{ Cotton } & \multicolumn{2}{|c|}{ Millet } & \multicolumn{2}{|c|}{ Maize } & \multicolumn{2}{|c|}{ Grounnuts } \\
\hline S. No .Scientifics names & $\mathrm{Fc}$ & CSP & $\mathrm{Fc}$ & CSP & $\mathrm{Fc}$ & CSP & $\mathrm{Fc}$ & CSP \\
\hline 1 Thelepogon elegans & 73.33 & 5.95 & 86.67 & 9.42 & 46.67 & 4.61 & 73.33 & 7.86 \\
\hline 2 Hyptis spicigera & 40.00 & 3.24 & 60.00 & 6.52 & 53.33 & 5.26 & 40.00 & 4.29 \\
\hline 3 Teramnus labialis & 40.00 & 3.24 & 33.33 & 3.62 & 33.33 & 3.29 & 53.33 & 5.71 \\
\hline 4 Nensonia canescens & 80.00 & 6.49 & 26.67 & 2.90 & 26.67 & 2.63 & 26.67 & 2.86 \\
\hline 5 Oldelandia corymbosa & 40.00 & 3.24 & 20.00 & 2.17 & 33.33 & 3.29 & 60.00 & 6.43 \\
\hline 6 Acanthospermum hispidum & 33.33 & 2.70 & 40.00 & 4.35 & 46.67 & 4.61 & 0.00 & 0.00 \\
\hline 7 Commelina nigritana & 46.67 & 3.78 & 20.00 & 2.17 & 6.67 & 0.66 & 40.00 & 4.29 \\
\hline 8 Borrheria villosus & 53.33 & 4.32 & 13.33 & 1.45 & 13.33 & 1.32 & 20.00 & 2.14 \\
\hline 9 Sorghum bicolor & 0.00 & 0.00 & 86.67 & 9.42 & 6.67 & 0.66 & 0.00 & 0.00 \\
\hline 10 Vernonia amygdalina & 26.67 & 2.16 & 20.00 & 2.17 & 0.00 & 0.00 & 46.67 & 5.00 \\
\hline 11 Penincetum pedicellatum & 40.00 & 3.24 & 20.00 & 2.17 & 20.00 & 1.97 & 13.33 & 1.43 \\
\hline 12 Arachys hypogea & 0.00 & 0.00 & 0.00 & 0.00 & 0.00 & 0.00 & 86.67 & 9.29 \\
\hline 13 Merrenia aegyptia & 6.67 & 0.54 & 20.00 & 2.17 & 26.67 & 2.63 & 33.33 & 3.57 \\
\hline 14 Zea mays & 0.00 & 0.00 & 0.00 & 0.00 & 86.67 & 8.55 & 0.00 & 0.00 \\
\hline 15 Ischaenum sp. & 20.00 & 1.62 & 0.00 & 0.00 & 33.33 & 3.29 & 33.33 & 3.57 \\
\hline 16 Corhorus olitorius & 26.67 & 2.16 & 20.00 & 2.17 & 40.00 & 3.95 & 0.00 & 0.00 \\
\hline 17 Gossipium hirstetum & 86.67 & 7.03 & 0.00 & 0.00 & 0.00 & 0.00 & 0.00 & 0.00 \\
\hline 18 Leucas martinisensis & 26.67 & 2.16 & 13.33 & 1.45 & 40.00 & 3.95 & 0.00 & 0.00 \\
\hline 19 Alysicarpus rugosus & 40.00 & 3.24 & 26.67 & 2.90 & 6.67 & 0.66 & 0.00 & 0.00 \\
\hline 20 Penicetum sp. & 6.67 & 0.54 & 13.33 & 1.45 & 13.33 & 1.32 & 26.67 & 2.86 \\
\hline 21 Euphorbia hirta & 6.67 & 0.54 & 0.00 & 0.00 & 26.67 & 2.63 & 26.67 & 2.86 \\
\hline 22 Thelepogon sp. & 26.67 & 2.16 & 0.00 & 0.00 & 0.00 & 0.00 & 33.33 & 3.57 \\
\hline 23 Setaria pumila & 0.00 & 0.00 & 0.00 & 0.00 & 0.00 & 0.00 & 46.67 & 5.00 \\
\hline 24 Senna tora & 0.00 & 0.00 & 13.33 & 1.45 & 20.00 & 1.97 & 13.33 & 1.43 \\
\hline 25 Commelina benghalensis & 13.33 & 1.08 & 6.67 & 0.72 & 26.67 & 2.63 & 0.00 & 0.00 \\
\hline 26 Peristrophe bicalyculata & 0.00 & 0.00 & 26.67 & 2.90 & 13.33 & 1.32 & 0.00 & 0.00 \\
\hline 27 Launaea cornuta & 0.00 & 0.00 & 0.00 & 0.00 & 40.00 & 3.95 & 0.00 & 0.00 \\
\hline 28 Bulbostylis hispidula & 13.33 & 1.08 & 6.67 & 0.72 & 0.00 & 0.00 & 20.00 & 2.14 \\
\hline 29 Borrheria chaetocephala & 20.00 & 1.62 & 20.00 & 2.17 & 0.00 & 0.00 & 0.00 & 0.00 \\
\hline 30 Sida rhombifolia & 6.67 & 0.54 & 6.67 & 0.72 & 20.00 & 1.97 & 0.00 & 0.00 \\
\hline 31 Penincetum polystachion & 13.33 & 1.08 & 13.33 & 1.45 & 6.67 & 0.66 & 0.00 & 0.00 \\
\hline 32 Sesbania pachycarpa & 13.33 & 1.08 & 6.67 & 0.72 & 6.67 & 0.66 & 6.67 & 0.71 \\
\hline 33 Cyperus esculentus & 20.00 & 1.62 & 13.33 & 1.45 & 0.00 & 0.00 & 0.00 & 0.00 \\
\hline 34 Teramnus repens & 20.00 & 1.62 & 6.67 & 0.72 & 0.00 & 0.00 & 6.67 & 0.71 \\
\hline 35 Physalis angulata & 20.00 & 1.62 & 0.00 & 0.00 & 0.00 & 0.00 & 13.33 & 1.43 \\
\hline 36 Paspalum podystachum & 26.67 & 2.16 & 0.00 & 0.00 & 6.67 & 0.66 & 0.00 & 0.00 \\
\hline 37 Striga hermontiga & 0.00 & 0.00 & 13.33 & 1.45 & 0.00 & 0.00 & 13.33 & 1.43 \\
\hline 38 Hibiscus esculentus & 0.00 & 0.00 & 6.67 & 0.72 & 6.67 & 0.66 & 13.33 & 1.43 \\
\hline 39 Celosia trigyna & 0.00 & 0.00 & 6.67 & 0.72 & 20.00 & 1.97 & 0.00 & 0.00 \\
\hline 40 Bidens pinosa & 6.67 & 0.54 & 6.67 & 0.72 & 6.67 & 0.66 & 6.67 & 0.71 \\
\hline 41 Impomea vagans & 6.67 & 0.54 & 6.67 & 0.72 & 6.67 & 0.66 & 6.67 & 0.71 \\
\hline 42 Kyllinga squamutala & 0.00 & 0.00 & 0.00 & 0.00 & 26.67 & 2.63 & 0.00 & 0.00 \\
\hline 43 Fimbristylis hispidum & 20.00 & 1.62 & 6.67 & 0.72 & 0.00 & 0.00 & 0.00 & 0.00 \\
\hline 44 Hydrolea glabra & 20.00 & 1.62 & 6.67 & 0.72 & 0.00 & 0.00 & 0.00 & 0.00 \\
\hline 45 Hygrosphyla aurienlata & 0.00 & 0.00 & 20.00 & 2.17 & 0.00 & 0.00 & 0.00 & 0.00 \\
\hline 46 Eragrostis tenella & 0.00 & 0.00 & 6.67 & 0.72 & 6.67 & 0.66 & 6.67 & 0.71 \\
\hline 47 Vernonia cinera & 0.00 & 0.00 & 6.67 & 0.72 & 6.67 & 0.66 & 6.67 & 0.71 \\
\hline 48 Vernonia galamensis & 0.00 & 0.00 & 6.67 & 0.72 & 6.67 & 0.66 & 6.67 & 0.71 \\
\hline 49 Phyllanthus amarus & 0.00 & 0.00 & 6.67 & 0.72 & 13.33 & 1.32 & 0.00 & 0.00 \\
\hline 50 Triumfeta pentendra & 0.00 & 0.00 & 6.67 & 0.72 & 13.33 & 1.32 & 0.00 & 0.00 \\
\hline
\end{tabular}




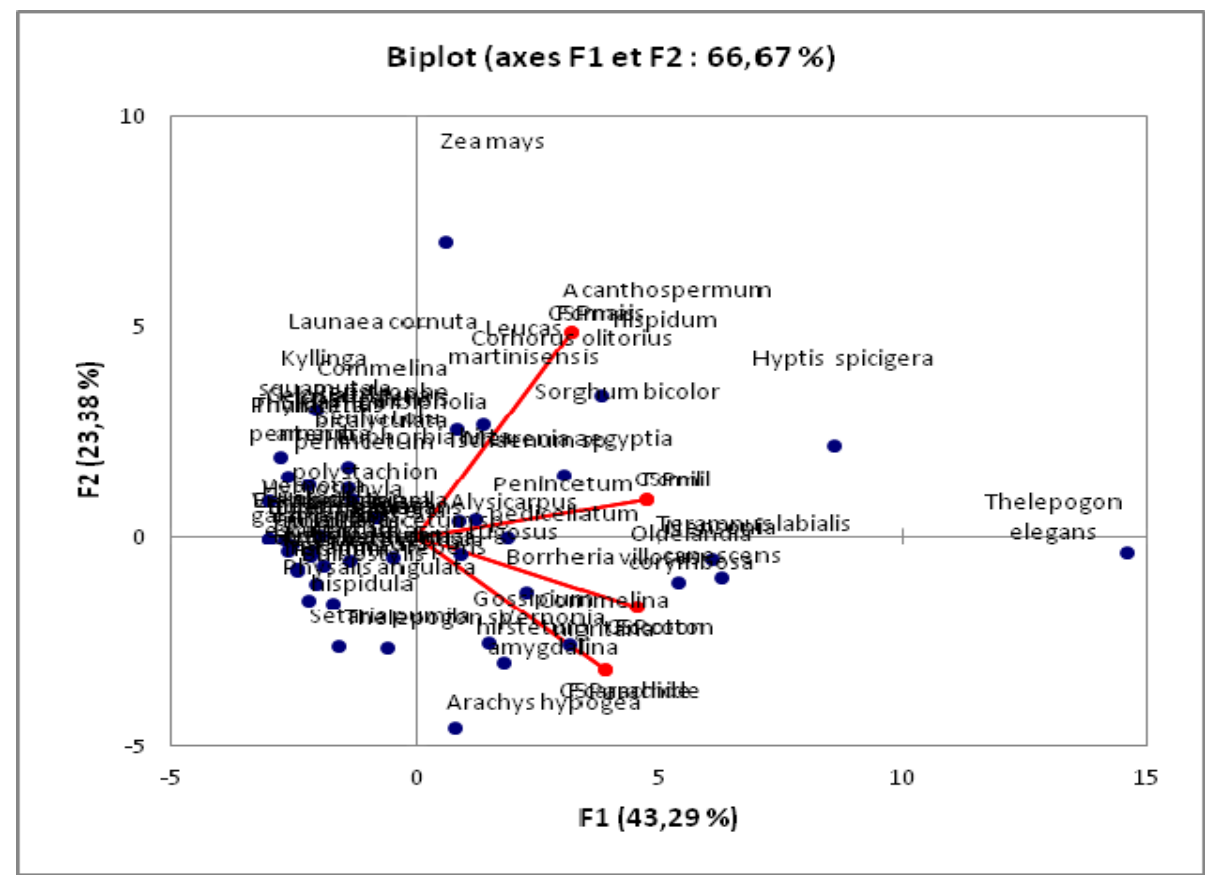

Fig. 10 Principal component analysis of CSP herbaceous species.

Table 4 Correlation matric of Pearson (n).

Fc: Centesimal frequencies; CSP: Specific contribution species.

\begin{tabular}{lllllllll}
\hline Variables & Fc cotton & CSP cotton & Fc millet & CSP millet & Fc maise & CSP maize & Fc grounnuts $\begin{array}{l}\text { CSP } \\
\text { grounnuts }\end{array}$ \\
\hline Fc cotton & 1 & 1.000 & 0.354 & 0.355 & 0.149 & 0.149 & 0.295 & 0.295 \\
CSP cotton & 1.000 & 1 & 0.355 & 0.355 & 0.149 & 0.149 & 0.295 & 0.295 \\
Fc millet & 0.354 & 0.355 & 1 & 1.000 & 0.274 & 0.274 & 0.253 & 0.253 \\
CSP millet & 0.355 & 0.355 & 1.000 & 1 & 0.274 & 0.275 & 0.253 & 0.253 \\
Fc maize & 0.149 & 0.149 & 0.274 & 0.274 & 1 & 1.000 & 0.097 & 0.098 \\
CSP maize & 0.149 & 0.149 & 0.274 & 0.275 & 1.000 & 1 & 0.097 & 0.097 \\
Fc graounnut & 0.295 & 0.295 & 0.253 & 0.253 & 0.097 & 0.097 & 1 & 1.000 \\
CSP graounnuts & 0.295 & 0.295 & 0.253 & 0.253 & 0.098 & 0.097 & 1.000 & 1 \\
\hline
\end{tabular}

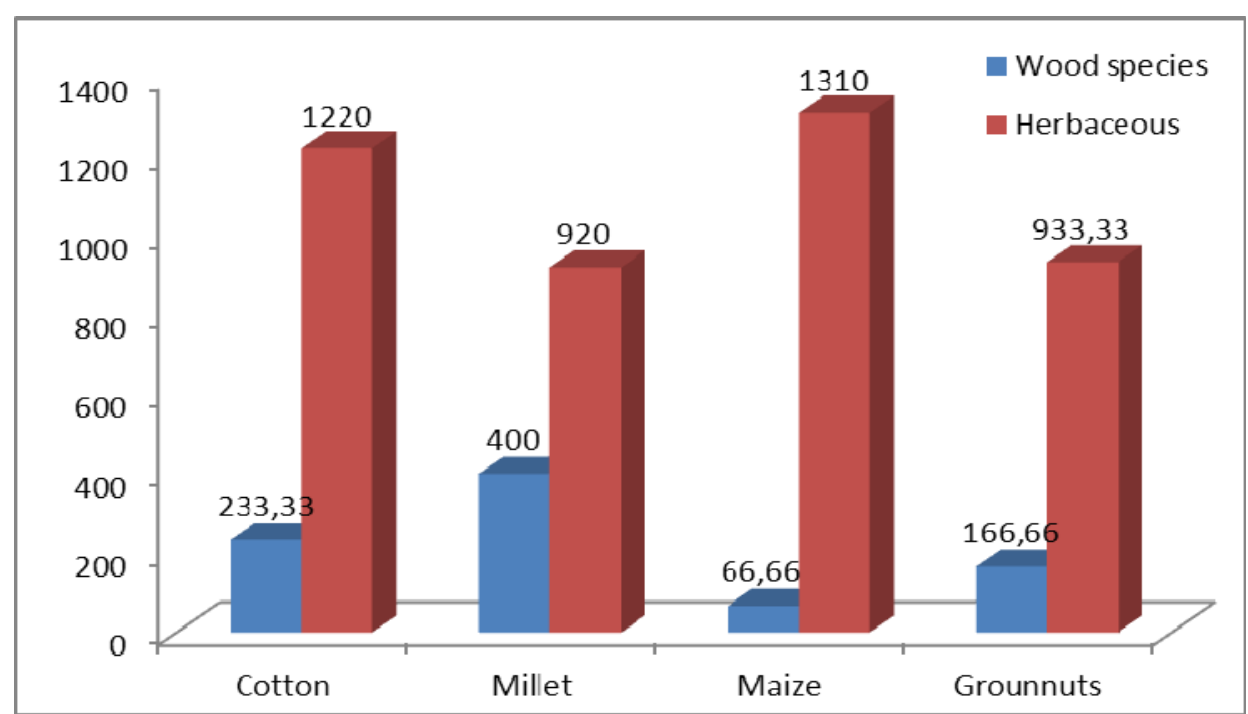

Fig. 11 Influence of farming practices on the recovery of herbaceous and woody species (\%). 
matter $(32 \%)$, the combination fallow and chemical fertilizers (18\%) and fertilizers (16\%) (Fig. 12). Practice population low fallow (10\%), to improve the fertility of their soils. However, some savvy growers the advantage of setting aside their field leave their crops to stand for 2 to 3 years by putting organic fertilizer.

\subsection{The Practice of Crop Rotation in Vridjibao}

Farmers practice crop rotation to increase crop yields and prevent soil depletion. Four types of rotation are practiced in the village (Fig. 13). The rotation of cotton/sorghum/sorghum more legumes (40\%), cotton is grown in the first year, the second year is for sorghum and sorghum more pulses in the third year.
The second type of rotation is the rotation sesame/cotton/sorghum/sorghum more legumes (24\%), rotation cotton/sorghum/groundnuts (22\%) and finally, the same culture for years $(14 \%)$.

\subsection{Intercropping}

The association is generally made between the cereal and or legumes. These are: sorghum groundnuts, sorghum, cowpeas, corn-soybean, corn-potato. The most practiced by the farmers association is millet-cowpea-hibiscus-squash (24\%). Other types of peanut-millet more sorrel squash associations $(23 \%)$, cotton, cowpea (18\%) and millet-dots-ground sesame (14\%) are also practiced in the village (Fig. 14). The cotton-bean combination seems to reduce today.

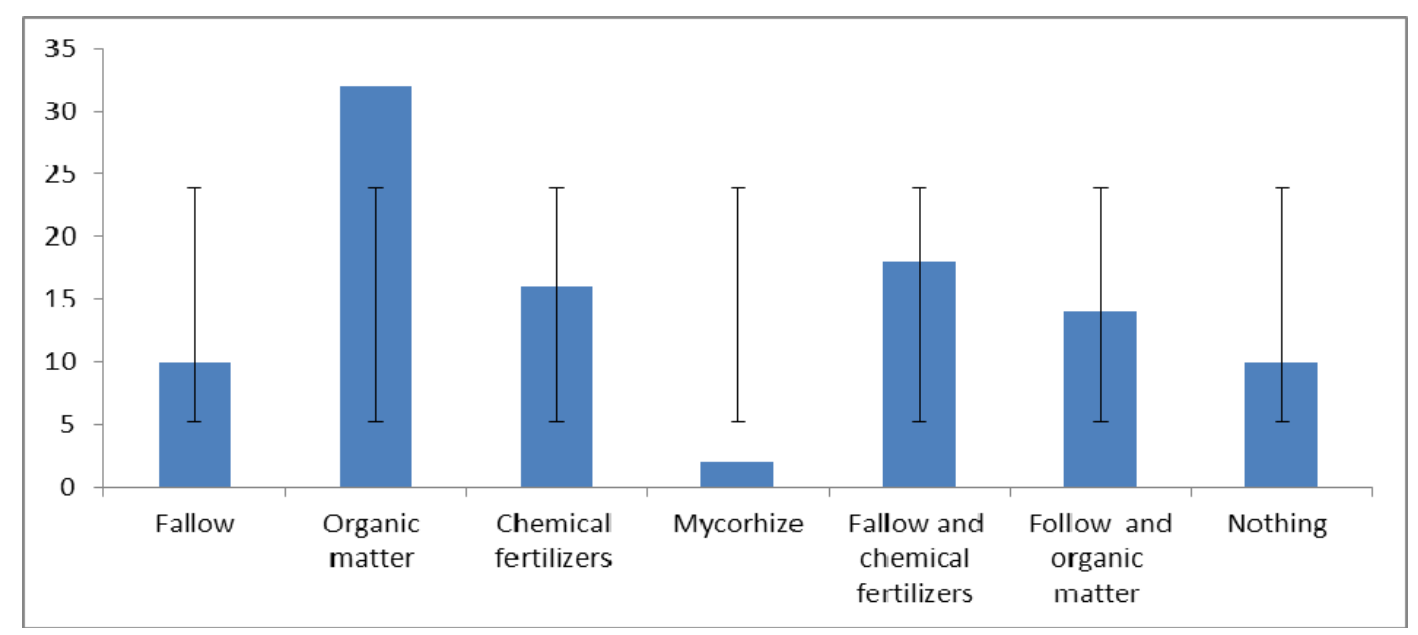

Fig. 12 Restoration techniques and fertilization in Vridjibao village.

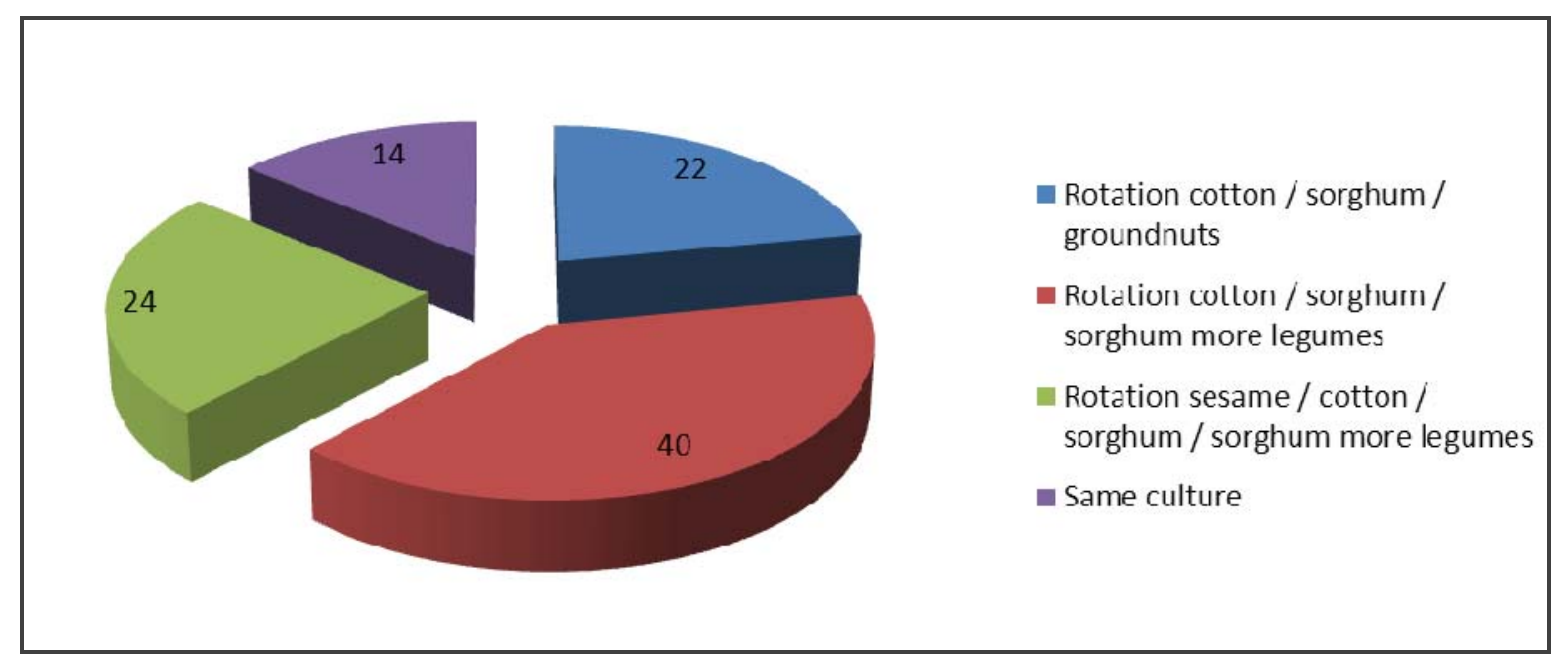

Fig. 13 Types of crop rotation (\%). 


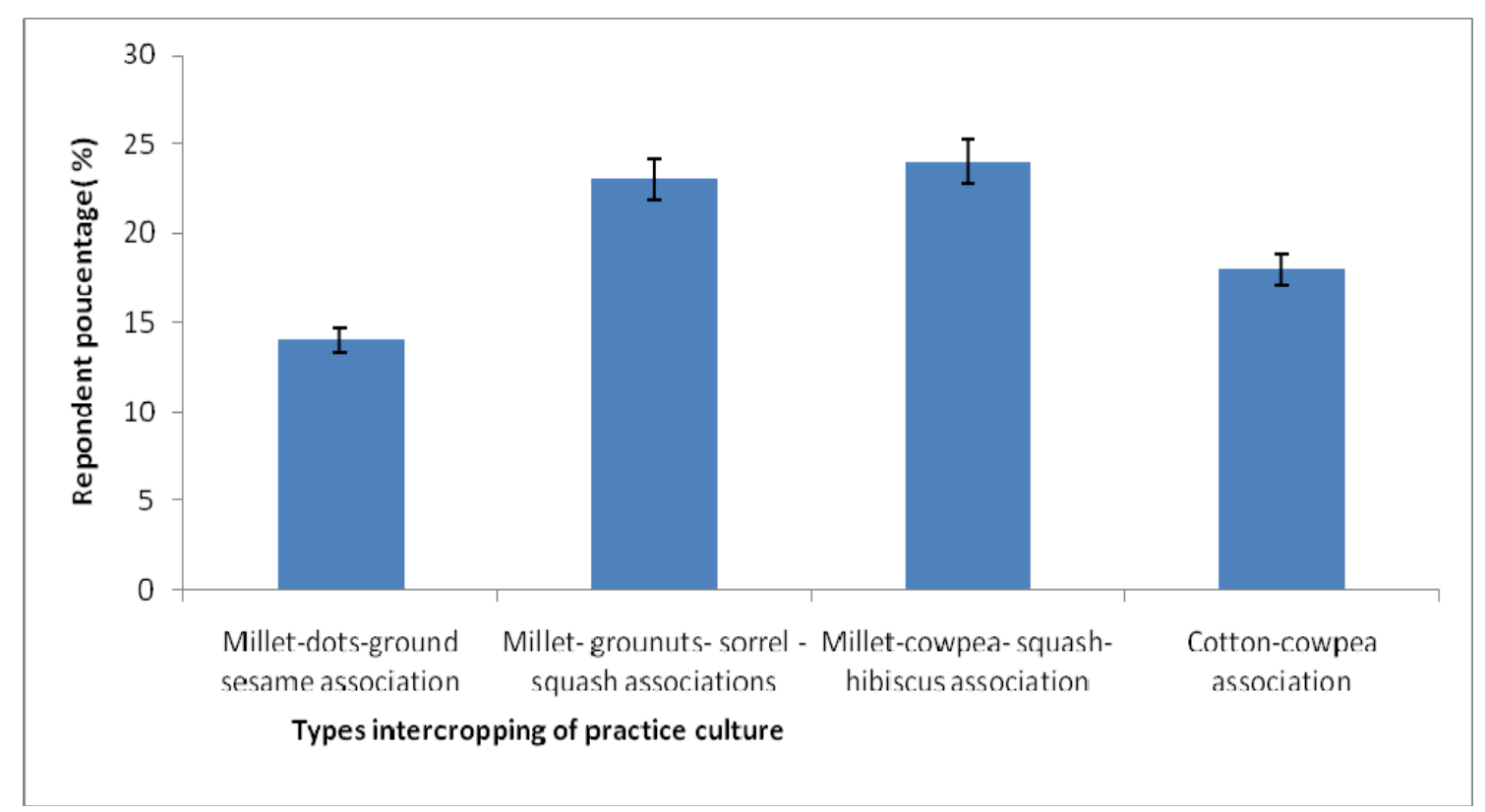

Fig. 14 Types of intercropping encountered in the village.

Because farmers have experienced the pods which are contaminated by chemicals used against pests of cotton. By combining several crops on the same field, we try to combine the advantages of crop rotation or rotation on the same field during the same year and also weeding is limited, so a method to encourage.

\subsection{Protection of Woody Species in the Fields and} Their Uses

The results of investigations raised 12 woody species that are protected in the fields. Among them, we find Adansonia digitata (16\%) Parkia biglobosa (14\%), Balanites aegyptiaca (12\%) and Vitellaria paradoxa (12\%) (Fig. 15). The figure 16 shows that domestic farmers keep more trees for food (40\%), traditional medicine $(19.43 \%)$ and ornament (15\%). In home gardens farmers grow island Zea mays, Sorgum sp., Hybiscus sp., Solanum melongena, Allium cepa, Solanum melongena, Hibiscus esculentus, Ipomea sp., Vigna unguculata, Capsicum futescens, Arachis hypogea, Hibiscus sabdaripha, Mangifera indica, Carica papaya, Manibot esculens, Psidium guajava.

\section{Discussion}

Among the techniques used by farmers to improve crop yields, the use of pesticides, herbicides and insecticides is essential but all times its misuse contributes to reducing the loss of biodiversity. These chemicals have depressive effects on the environment and vegetation $[3,6]$, found that corn, millet and peanuts give a good performance, but cotton does not down. Similar work was carried out in the department of Mayo Dallah and that is cotton which has a large area, but low production [7] which shows that the cotton is being discontinued by cotton farmers [3], found that farmers do not grow only to ensure food self-sufficiency, but the profit, because food crops are, nowadays, a source of income [8], hilling positive influence on plant biomass and yield. In March-April, the lake was cut in half at the bridge Lao (PRODELKA). These facts are similar to those [2], and noted he quoted: Cropping practices led to erosion, desert encroachment, and destruction of forests, land degradation, drought, changing climate patterns and reduced rainfall. Erosion can be reduced by the construction of bunds and planting trees around the fields. Farming practices influence on tree height for protected positively and negatively feet cut feet. Most of wood is found in the fields from the rejection of the stem and it confirms the result [9]. Limited studies 


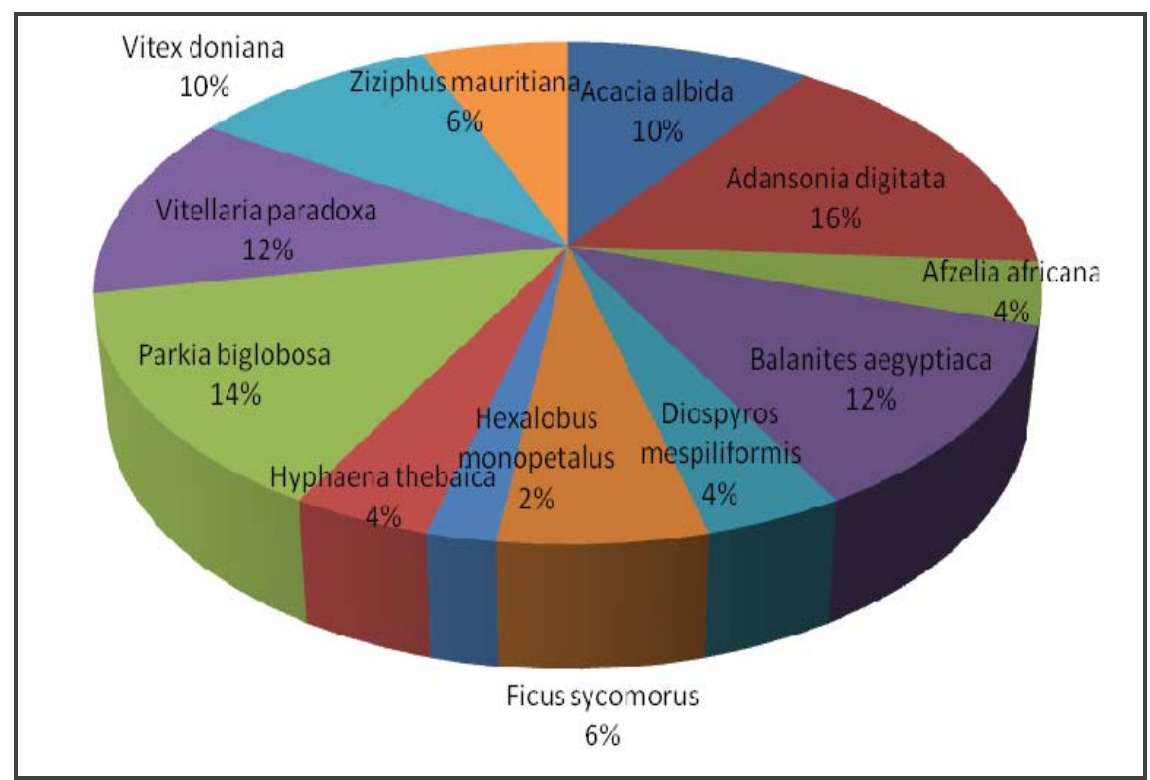

Fig. 15 Protected wildlife in the fields (\%).

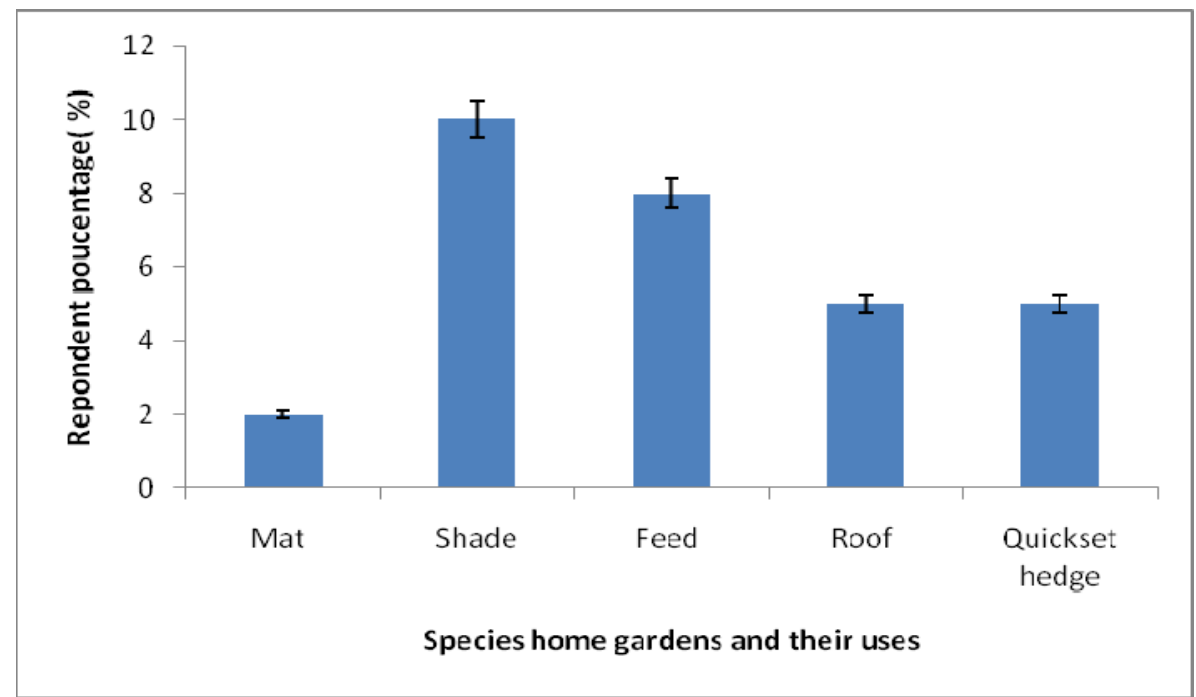

Fig. 16 Use of species home gardens (\%).

indicate that when there is an accumulation of organic debris, the lateral extension is better yet, the lateral development is inhibited when water accumulation [10]. [11] found from their work that the majority of wood is left with a lower DBH $0.5 \mathrm{~m}^{2} /$ ha in the field and what is the result of our work (about 15 species, 5 only have a greater than $0.5 \mathrm{~m}^{2} /$ ha diameter). This is justified by cuts in emissions in each field preparation. Similar works by [12] in the Far North of Cameroon showed that pressures farming practices have the effect of increasing the diversity of the herbaceous layer, but lower than the woody stratum. This result is similar to the work of [13] on spatial heterogeneity and dynamic renewal of a forest. This author has shown that there is a correlation between the density, basal area, height and diameter. For four treatments maize, millet, peanuts, and cotton, the principal component analysis revealed that the height of the trees in the millet field is positively correlated to include basal area of trees in the field of millet, tree basal area in peanut field. Today the disappearance of these species shows that they do not stand up to the 
practice and also the action of man, this was also noted by the work done [9] in the Far North of Cameroon on weeds Post cultivation. The method is to encourage fallow for two major advantages: the reconstruction of plant species and soil enrichment. According to farmers, there are residual effects of crop (or rear impacts). The manure made on farming, usually leave in the soil as a fertilizer uses the following crop residue. In the same way, [4] working on intercropping, found it helps to suppress weeds and increase soil porosity. The rotation helps to control weeds by alternating crops rapid development and dense (potato) with other special reduced development. The long-term rotation of grain/vegetables decrease the effect of nematodes on Solanaceae, these nematodes do not attack cereals. As crop rotation it is very rarely used in the fight against Striga hermontica because of the high seed longevity (12-20 years). In this system, the choice of varieties is based on performance and adaptation to mechanization. Monoculture is a practice which results in plant susceptibility towards pests: the fact of maintaining a single plant species in one place leads to the selection of very formidable pests and reduced biodiversity. On insects it was noted that the Association mil/cowpea significantly reduced attacks thrips on cowpea. This is because thrips are retained in the canopy of millet cobwebs. The same is true of the sorghum/cowpea intercropping on Maruca vitrata whose impact on the yield of cowpea was reduced by 46. Solarization is a hydrothermal phenomenon, which means that the water content of the soil should be high (at least $70 \%$ of the hydrothermal ability) to get a good transfer of heat to organism control. Solarization good results against some nematodes (Meloidogyne spp.) seeds pathogens (Rhizoctonia solani, Verticillium dahliae, Fusarium solani) and some weed seeds and plant pests (Orobanche spp.). However, it is only profitable for very intensive crops, such as vegetables in small areas. Protection of trees in the field, this result has an agreement with the work done in southern Chad in the region of Logone Oriental.

\section{Conclusions and Recommendation}

The objective of the study was to propose methods of environmental management to improved living conditions of the population of Chad and in particular the township Erdé-pala and the preservation of biodiversity on earth. The fields are overgrown with weeds growing. The installation of uncontrolled fields led to the destruction of forests. It is recommended that civil and administrative authorities to teach from an early age, the concept of protection and preservation of plant resources for children. It is strongly recommended to protect the trees in the fields and preserve species extinction pathways. It would be very useful to train farmers in good agricultural practices to conserve soil. To mitigate environmental degradation and communal clashes, the local villagers should be divided into three parts which are the operating units. For reason of forest restoration, the agriculture should be strongly focused on agroforestry preferably based local species. Farming clearing techniques must be improved in order to make them less destructive to vegetation, fallow land must be respected. To increase the production of plant cover is down and promotes regeneration; environmental education of the local population on farming techniques should be considered and supported by the Administration. Agriculture and livestock association should be encouraged for traction and manure.

\section{Acknowledgments}

We gratifully satisfied by the ERD Pala population for their contribution of this paper.

\section{Reference}

[1] Reounodji, F. 2003. Espaces, sociétés rurales et politiques de gestion des ressources naturelles dans les savanes du Tchad. Vers une intégration agriculture, élevage. Thèse de Doctorat de géographie, Paris: 403.

[2] Charriere, G. 1984. "La culture attelée: un progrès dangereux." Cahier ORSTOM 20 (3-4): 647-56.

[3] Gapili, D. 2008. La dynamique agriculture et son impact sur les ressources naturelles: cas du Canton Erdé-Pala. Mémoire de Maîtrise, Université de Ndjamena. 
[4] Dagou, P. 1986. Les milieux ruraux en Afrique au sud du Sahara: cas du pays Moundang au Tchad. Thèse de Doctorat du ${ }^{3 i e ̀ m e}$ cycle de Géographie; Université Paul Valery (Montpellier), Paris.

[5] Baohoutou, L. 2007. Les précipitations en zone soudanienne tchadienne durant les quatre dernières décennies: variabilités et impacts.

[6] Haudricourt and Michel. 1955. L'homme et la charrue à travers le monde, réédité dans la technologie le sacré et le profane, Paris, Gallimard NRF, p. 187.

[7] Madjadoum, N. 1997. Agriculture de subsistance, culture d'exportation, problèmes de Bedan, un village tchadien, Maitrise, Université de Paris 8 Vincennes, p. 72.

[8] Ahanchidé, A. 2000. Compétition entre les mauvaises herbes et cultures cotonnières: influence du nombre de sarclages sur la biomasse et le rendement. Université du Cotonou-Benin, p. 151.

[9] Donfack, P. 1993. Etude de la dynamique de la végétation après abandon de la culture au Nord Cameroun. Thèse $3^{\text {ème }}$ cycle. Université de Yaoundé Cameroun. p. 180.

[10] Lerberghe Van Philippe. 1999. Influence du travail du sol sur la stabilité des peuplements. IDF Antenne de Toulouse 7, chemin de la Lacade, Auzeville-Toulouse. p. 228.

[11] Halimatou, B. 2010. Caractérisation biophysique de ressources ligneuses dans les zones dégradées et reverdies au Sahel: cas du Département de Mayali, Mémoire de DEA, Université de Niamey au Niger, p. 69.

[12] Donfack, P. 1998. Végétation des Jachères du nord Cameroun. Typologie, diversité; dynamique, production, thèse troisième cycle, Université de Yaoundé I., p. 225.

[13] Péléssier, R. 1995. Relation entre l'hétérogénéité spatiale et la dynamique de renouvellement d'une forêt dense humide sempervirente, Thèse de Doctorat, Université Claude Bernard, Lyon 1, p. 244.

[14] Stephane de Tourdonnet 2008. "Utilisation des cultures associées en semis direct." Le portail des agricultures 46 : 12. 